\title{
Advance Price Agreement: An Option to Reduce Controversy Between Multinationals and Tax Administrations
}

\author{
Sarah Nait Taadouit ${ }^{*} \quad$ Badr Habba $^{1,2} \quad$ Taib Berrada El Azizi ${ }^{2}$ \\ 1.LAREGO Laboratory, ENCG, Cadi Ayyad University, Rue Amarchich, Marrakech 40000, Morocco \\ 2.ESCA School of Management, Rue Abou Youssef El Kindy, Casablanca 20070, Morocco
}

\begin{abstract}
The research is financed by Asian Development Bank. No. 2006-A171(Sponsoring information)
Abstract

This paper explores the disparities existing between multinational corporations (MNCs) and tax administrations in terms of transfer pricing strategies. Because transfer pricing is actually considered the main tax issue in the international taxation, tax authorities' regulations have an important role when it comes to transfer pricing policies. In one hand, the manipulation of transfer prices (applied by MNCs) results in important losses in a country's tax revenue, and thus, create inequalities between nations. In another hand, transfer pricing tax adjustments (applied by tax authorities), result in significant costs for MNCs. Accordingly, these two parties are forced to work together in order to find a fair consensus. The OECD has introduced the Advance Price Agreement (APA), which can be concluded between a MNC and one or many tax administrations. It provides certainty to the MNC regarding the transfer pricing method selected. However, this process can be hard to achieve for MNCs, which need to openly collaborate with many tax authorities, and therefore, expose themselves to important risks. In this respect, this exploratory qualitative study mobilises both the Agency Theory and the Stewardship Theory when analysing this dichotomous relationship between tax administrations and MNCs in respect of transfer pricing strategies.
\end{abstract} Keywords: Transfer Pricing, Multinational Corporation, Tax Administration, Advance Price Agreement DOI: $10.7176 /$ RJFA/11-24-11

Publication date: December $31^{\text {st }} 2020$

\section{Introduction}

Transfer pricing has largely been a subject of many management sciences researches, various disciplines have studied the transfer pricing problematic, in particular: economics, taxation, law and accounting. This is because, it is actually considered as the main tax issue (OECD, 2017). In fact, the different tax regimes adopted by the countries, encourage multinational companies to implement tax optimisation practices, through their subsidiaries. Accordingly, transfer pricing is considered the main tool for tax optimisation. Tax administrations and multinational enterprises can sometimes have contrasting objectives when it comes to transfer pricing strategies.

In one hand, the international trade evolution is forcing companies to locate their activities in various countries around the world. These companies aim to ensure strong economies of scale, increase productivity and competitiveness, and also optimise the costs' structure. Accordingly, in order to achieve these organisational goals, MNCs choose certain methods to fix their transfer prices. These methods are set by laws and regulations, to maintain fairness between all the parties. Consequently, before choosing a transfer pricing method, MNCs should consider tax implications of each jurisdiction, however, a MNC may manipulate its transfer pricing strategies, in order to legally shift its profits to low tax jurisdiction, and reduce its global profit.

In another hand, due to the recent financial crises, many countries have adopted some measures of austerity to rebalance their public finances such as tax rises and public expenditure cuts etc. Therefore, the political and public attention has inevitably drawn to companies which tend to avoid paying their fair share of taxes. This avoidance is generally executed by the mean of manipulating the transfer prices of the intercompany transactions. Tax authorities are encouraged to adopt international guidelines (OECD, 2017) in terms of their internal transfer pricing policies, in order to limit illegal profit shifting practices.

As a result, it is important for tax administrations and MNCs to agree on transfer pricing models to be applied. These methods must be based on the arm's length principle. MNCs select the best method to use for a certain type of an intercompany transaction, according to their business models, and on the basis of different analysis. The selected method should undoubtedly be compliant with the tax regulations. However, it can be rejected by the concerned tax administration depending on the internal tax policies of the jurisdiction. Thus, the opposition between the tax administrations and the MNCs, may influence the transfer pricing strategies. Furthermore, it has been noted that there is a difference between developed and emerging countries in transfer pricing treatments. In fact, emerging countries may adopt low regulated tax policies, in order to attract foreign investment (that generate more value in the economy, by creating jobs and increasing the country's corporate tax revenues). These measures may impact MNCs when implementing their transfer pricing policies, by choosing to put the entities that create the highest value in those types of jurisdictions.

Transfer pricing is considered an art and not an exact science, this leads to have different interpretation on what is the best transfer pricing practice. A company's top priority is the business, then follows tax. In this respect, 
a multinational enterprise would choose the jurisdiction in which the business will do well first, then consider the tax implications. However, because the tax authorities draw a critical attention to intercompany transactions prices, MNCs need to make sure their transfer prices structures are compliant. The OECD has introduced different measures to make sure transfer pricing rules are being respected, and reduce conflicts that may rise between the MNCs and the tax administrations. The Advance Price Agreement is an arrangement that can be concluded between a MNC and one or many tax administrations, in order to provide certainty that the transfer pricing method selected is the most convenient one to be used. Tax administrations encourage MNCs to adopt this process, however, it can be considered as problematic for MNCs for different reasons.

This article is, therefore, an exploratory research which objective is to study first, the importance of transfer pricing for both MNCs, the tax administration's impact on transfer pricing choices, and determine whether APAs can be considered an option to reduce disagreements between tax administrations and multinational enterprises.

\section{Literature Review}

The theoretical literature on transfer pricing finds its basis in the studies of Hirshleifer (1956), Horst (1971) and Copithorne (1976). According to Hirshleifer, a transfer price should be determined in order to maximise the MNC's overall profit. He argues that transfer prices are equal to marginal costs of production. Copithorne studies the topic of transfer pricing in an international context and government policy. He argues that these prices are not related specifically to the global profit maximisation, and that the value is closely related to the organisational objectives of the management. Horst argues that MNCs use transfer pricing for intercompany transactions in order to minimise the overall taxes due. From this perspective, he confirms that multinational firms determine the level of transfer prices only to maximise the profit after tax. An important number of researches has been conducted on the basis of different theoretical perspectives and empirical approaches. Both the theory and the literature on this subject have been examined in the framework of the Organisational theory1 (Watson and al, 1975), and also the Contingency theory2 (Solomons, 1965).

Transfer pricing has become the most major concern for MNCs and tax administrations internationally (Mulyani, 2010). It has been a subject of many academic research for the past decades (Luft \& Libby 1997, Kachelmeier \& Towry, 2002). The complexity of transfer pricing has led researchers to study it under many different approaches, such as: control, accounting, modelling, organisational structure, corporate strategy and finally taxation. Transfer pricing literature 3 can be divided into two main categories: taxation and management. Taxation approach includes optimisation, compliance and audits, whereas management approach 4 includes managers' motivations and objectives, as well as resources efficient allocation. In order to have a full understanding of our research's object and its purpose, it is essential to develop some opinions and the theoretical background of transfer pricing practices.

\subsection{Transfer pricing: MNCs motivations}

Transfer prices are the prices at which tangible and intangible assets, goods and services, raw materials, and technology are transferred from one entity to another related entity at arm's length (Davidmann 1996, Aranoff 2000). Therefore, each company needs to implement a transfer pricing strategy. These policies are set depending on the company's overall objectives. However, MNCs implement transfer pricing strategies for three main reasons: the efficient use of internal resources, the achievement of the financial and organisational management strategies, and finally, the tax compliance (Urquidi, 2008). Setting a transfer pricing strategy allows MNCs to increase their market shares globally (Nielsen and Schjelderup, 2001). Conversely, abundant literature argues that MNCs set their transfer pricing strategies for purely fiscal reasons (Kimberly 1998, Choe and Hyde 2004, Korn and Lengsfeld 2004). It is clear that transfer pricing is considered, essentially, the main tax issue from the international taxation perspective. However, many MNCs aim to ensure that their transfer pricing practices remain compliant with the different tax regulations of the countries where they operate. The tax regimes disparities allow MNCs to adopt tax optimisation objectives when setting their transfer prices. In this regards, some MNCs may adopt aggressive tax optimisation practices, or even, tax evasion. Through, transfer pricing, a MNC can abusively transfer its profits to a low tax jurisdiction, the aim is to maximise its consolidated profit after tax. It should be noted that because this practice is illegal (but remains feasible), many tax authorities are adopting legal and tax measures in order to restrict illegal profit shifting from one jurisdiction to another. Many researchers (Urquidi and Thompson 2010, Sikka and Willmott, 2010) show that the large tax revenue losses resulting from the aggressive use of transfer pricing by MNCs have led the tax authorities to focus their tax audits on transfer pricing aspects. They have claimed that tax authorities around the world have begun to assess the intragroup transactions during their tax audits5. It is then clear that the existence of manipulation of transfer prices evidence by MNCs, has caused the implication of tax administrations when it comes to MNCs' transfer pricing strategies. However, it is unfair to automatically relate transfer pricing to manipulation for profit shifting objectives6.

In fact, Cravens (1997) has argued, that the main reason of setting a transfer pricing system is for competitive advantage purposes, this is explained by the fact that transfer prices have a large impact on the entity's global performance, and generally contribute to the achievement of the different objectives. Generally, foreign 
subsidiaries are considered as profit centers, therefore, their managers' outputs are measured and depend on the profits made by these subsidiaries. Consequently, transfer pricing can be controlled internally, both to motivate these entities' managers and to monitor their performance. Dunning (2000) has developed some MNCs' motives for transfer pricing, these have been completed in Chang (2010) contributions, they can be classified into, firstly, internal motifs such as: the economic profit maximisation, the price adjustment assistance, the anti-dumping policies control avoidance, costs cuts (taxes, salaries, operational costs), the new subsidiaries assistance and support, and also the competitiveness strengthening. Secondly, external motifs, such as: tax optimisation (overall consolidated tax and customs duties minimsiation), global profit maximisation, currency risk limitation, profit and capital correct allocation, and also increase the company's assets value.

Lin (2006) suggests that the main reasons of applying transfer pricing strategies are as follows:

- Enhanced market competitiveness: in order to improve a new product's competitiveness in a new foreign market, a company should set a competitive price. Therefore, MNCs tend to set lower transfer prices of products transferred between its related entities, to be able to ensure a low price for the new product.

- Flexible transfer of internal funds: In order to simplify their global fund management, MNCs tend to transfer funds from a local subsidiary of a host country through high transfer in and low transfer out prices.

- $\quad$ Alleviate tax burdens: In order to reduce tariff costs of the importing subsidiary, a MNC may apply low transfer prices practices. They can also aim to reduce the global income tax, in this case, MNCs may take advantage of the parent-subsidiary or subsidiary-subsidiary adjustments and also of their transfer pricing strategies.

According to Liu (2017), the main reason of setting a transfer pricing policy is to maximise the overall profit. The issue is that MNCs should respect the transfer pricing regulations, and therefore, they are not free in respect of their intercompany exchanges and transactions.

\subsection{Transfer Pricing: Tax administrations motivations}

Although there are many non-tax related reasons for a MNC to adopt transfer pricing strategies, some can be in a position where a transfer pricing manipulation would result to an illegal profit shifting, and therefore to a tax evasion. Tax authorities are aware of the transfer pricing policies' importance. Many countries are adopting unified approaches when dealing with transfer pricing audits and controls. The OECD has introduced guidelines and developing methods to be used. These can be regrouped into five methods: Comparable Uncontrolled Price, Cost Plus, Resale Price, Profit Split and Transactional Net Margin Method. These are all founded on the arm's length principle. Depending on the nature of the transaction, a MNC can choose one of these methods when fixing a transfer price. Many countries are adopting these measures in their transfer pricing internal policies and regulations. The aim is to avoid profit shifting practices, and limit tax evasion. The difficulty when setting control and audit procedures, is the complexity of MNCs' nature, operating in a perplexing and changing environment. The tax rules intended for these entities differ from one country to another. Therefore, these cannot be treated separately, but should be analysed in wide international context (OECD, 2011). It should also be noted that the progressive work accomplished by the OECD in respect of transfer pricing updates, is specifically designed to reduce confrontations between MNCs and tax administrations. It is for that respect, that so many countries inspired their internal transfer pricing policies on the basis of the OECD guidelines. Furthermore, differences between countries can, most of the times, be seen as an advantage for MNCs. These use the differences existing between the different jurisdictions, in order to shift profits and minimise their costs, especially, their tax charges. This is the main reason why countries are now unifying their transfer pricing rules.

It is undeniable that tax administrations play an essential role in transfer pricing strategies. The unique motivations for tax administrations in respect of transfer pricing strategies, is to protect their tax revenue, by limiting profit shifting practices and aggressive tax optimisation practices. Recently, international taxation has focused its attention on transfer pricing policies, this is because transfer pricing drives the relocation of corporate profits, tax evasion and capital flight. It has important unfair consequences in the context of global wealth distribution (Oyelere and Emmanuel, 1988; Gramlich and Wheeler, 2003; Baker, 2005). In this respect, the American tax administration considers the subject of transfer pricing as one of the most challenging topics it faces (The Times, 2010). It is also said that transfer pricing has an important impact on national tax policies, this is mainly due to the economic importance of intragroup exchanges, which constitute the majority of international trade (Sava and Tureatcā, 2017). In addition, international tax evasion practices are in continuous growth. In this respect, the OECD has conducted an analysis affirming that less than $10 \%$ of capital companies represent about $80 \%$ of global profits. Consequently, many researchers and financial analysts are encouraging the necessity of adopting unified solutions to the shared transfer pricing problematic. From this perspective, many specialised institutions are presenting transfer pricing models to be adopted in respect of different commercial, financial or patrimonial transactions. The aim is to protect national interest in relation to each jurisdiction, without prejudice to free competition (Sava and Tureatcā, 2017). This is the main challenge facing the different countries, which are now adopting measures aiming to maintain a unified transfer pricing approach. 
MNCs and tax authorities have different motivations in respect of transfer pricing strategies. Although, these companies have many non-tax related reasons to adopt a certain transfer pricing policy, they should respect transfer pricing regulations, and maintain tax compliance in respect of these strategies. A MNC can be free in choosing its transfer pricing method, based on the organisational and financial objectives set. However, the tax administration makes sure that the transfer pricing tax compliance is well respected. The complexity for the MNC is to set its organisational goals under the fiscal and legal transfer pricing framework. Whereas, the difficulty for tax administrations is to distinguish between a fair tax optimisation and an aggressive tax optimisation or tax evasion. This contradiction between organisational motives (especially tax optimisation objectives) sought by MNCs when fixing transfer prices to their intragroup transactions, and regulation motives (especially profit shifting and tax evasion prevention) assured by tax administrations, drives these both parties in finding mutual solutions to avoid conflictual positions.

\subsection{Advance Pricing Agreement: a solution?}

In order to limit the oppositions between tax administrations and MNCs in respect of transfer pricing practices. Many jurisdictions have opened the way to negotiations, by implementing different procedures, such as the Advance Price Agreement 7 (APA). According to the OECD (2017), an Advance Price Agreement is an arrangement which determines in advance, for intragroup transactions a number of criteria, particularly, the selected transfer pricing method, the comparables, as well as the adjustments to be made, as part of the determination of transfer prices for a given transaction in a determined period. Generally, an APA is initiated by MNCs, it is based on negotiations between the multinational related entities and one or many tax administrations related to the jurisdictions in which these multinational carry their activities. In fact, APAs complete the existing traditional mechanisms set in order to resolve transfer pricing problematics, such as audits and tax investigations conducted by tax authorities. APAs can therefore be useful when the traditional approaches fail to resolve disputes that may exist between MNCs and tax administrations in respect of transfer pricing policies. APAs generally deal with factual issues and methods adopted, whereas, traditional approaches tend to be limited to legal issues based on facts presented by the questioned entity. APAs measures go through the whole process of setting a transfer pricing strategy, from the comparables selection in terms of comparability analyses to the determination of the best method to be used.

Therefore, when the arrangement's conditions are well respected, APAs provide assurance that the treatment in accordance with the transfer pricing agreement is respected by both the MNC and the tax administration for the period covered (generally four years). However, this agreement only guarantees, that the selected transfer pricing method will not be subject of a tax administration audit. This being said that this agreement, does not prevent the tax administration to audit other aspects of the MNC's transfer pricing strategies (Borkowski, 2008). Also, the primary motive of setting an APA is the elimination of a potential double taxation (OECD, 2017). It is clear that, from transfer pricing perspective, the jurisdictions aim to maximise their tax revenues that may be shared with other jurisdictions. Hence, implementing an APA with the different concerned jurisdictions avoid the double taxation risk. APAs are a useful tool that resolve many legal, administrative and conventional problematics in respect of transfer pricing (Brem, 2005). Therefore, according to Brem (2015), the APAs' motives can be summarised as:

- Simplify key negotiations, practices and cooperatives between tax administrations and MNCs,

- Resolve all transfer pricing problems in an affective and prospective way,

- Use all tax administrations and MNCs resources in an efficient way,

- $\quad$ Provide more predictability to MNCs.

Concluding an APA remains beneficial for MNCs, that aim to secure their transfer pricing choices and policies. This agreement saves a lot of time and costs, and ensures that the selected transfer pricing method is correct. Thus, collaborations between tax administrations and MNCs become flexible, and are based on trust. This also guarantees a risk limitation of penalties and transfer pricing adjustments (Harden and Biggart, 2004; Markham, 2005; Ernst \& Young, 2008). APAs can also be considered as an opportunity, because they can reduce and even eliminate tax audits and controls performed by tax authorities. This means that all the process is primary accomplished in the beginning by mobilising the efforts of both MNCs and tax administrations. From this perspective, tax administrations can therefore, reduce their costs related to transfer pricing policies audits (Harden and Biggart, 2004).

An APA can take three forms, it can be unilateral, bilateral or multilateral. A unilateral APA concerns an arrangement with one country's tax authority, a bilateral APA concerns an agreement with two countries' tax authorities, and finally, a multilateral APA is an arrangement between a MNC and more than two tax authorities8. Borkowski (2008) has shown through his research, that bilateral and multilateral APAs are easily negotiated with tax administrations that already have double tax treaties conventions.

It is clear that implementing APAs can be considered as a primary mean of ending international conflicts, even before it begins (Adams and Coombes, 2003). Because MNCs are operating in a complex environment 
regulated by the international taxation regulations, they are encouraged to conclude these arrangements, in order to secure their intragroup transactions. However, in order for the negotiations to be efficiently successful, MNCS need to be cooperative and provide tax administrations all the requested documents and information (generally sensitive information). MNCs get two options, either choose their transfer pricing models and argue their methods during tax administrations' audits, or collaborate with the tax administration in order to define together the best method to use, and avoid being redressed on transfer pricing policies.

However, many organisations remain distrustful towards APA procedures. Although, it's very encouraged to collaborate with the tax administration, some MNC's stay cautious, when it comes to exposing all their information to the tax authorities, especially when the sensitive information is shared between many jurisdictions and misused on some areas. Transfer pricing regulations can also be weak and unstructured in some countries (especially in the emerging countries), this situation doesn't support MNCs to choose negotiation procedures. Thus, although APAs may present many advantages for both MNCs and tax administrations, this process may also encounter many complications. In fact, APAs engage a lot of costs and resources for both parties. The negotiations require transfer pricing, economic, tax, and financial specialists, which increase human resources costs for instance. The entire process requires also an important amount of time, therefore, MNCs need to be aware of the time that needs to be invested in the APA's conduct.

APAs have been introduced in order to resolve many transfer pricing complications, due to the opposition between the tax administrations and the multinational organisations. These entities are in a position where they have to assume the different environment risks (mainly tax risks), or adopt a participative procedure and proceed with the negotiation in order to close advance price arrangement with the different tax authorities involved. Therefore, they secure internal group transactions pricing policies, and maintain an effective tax compliance. It should be noted that many countries have adopted this procedure in their transfer pricing policies, due to it bright input in reducing conflicts in terms of transfer pricing strategies. The procedure of APAs can be easily undertaken in regulatory structured economies. Conversely, it can be very hard to implement in a country where transfer pricing legislation is fragile, such as emerging countries.

\section{Theoretical Guidance}

Tax administrations largely influence multinational organisations functional behaviors. Thus, the existence of this close link between both parties, create a sort of complex relationships, that can either result in agreements or conflicts. Transfer pricing strategies is one of the most important topics argued between MNCs and tax administrations. Because both of them have, sometimes, contradictory motivations in regards to transfer pricing policies (particularly, when MNCs set tax optimisation as their main transfer pricing strategy's objective). It is evident that the key goal of a company's internationalisation strategy is to maintain an efficient economy of scale, especially by minimising the tax costs. In this respect, the confrontation with the different tax authorities involved is highly attainable. It is crucial to study this relationship under both the Agency theory and the Stewardship theory. The Agency Theory has been abundantly used in many researches in respect of different disciplines, such as accounting (Demski and Feltham, 1976), economy (Spence and Zeckauser, 1971), finance (Fama, 1980), marketing (Basu, Srinivasan and Staelin, 1985), political sciences (Mitnick, 1986), organisational behavior (Kosnik, 1987), and also sociology (Eccles and White, 1985). According to this theory, each organisation is constituted by a number of contacts9. These contracts define the relationships maintained between the Principal and the Agent. The participants classify these relationships under many categories, for instance: the agency relationships. In order to qualify a connection as an agency relationship, three conditions need to be completed. Firstly, informational asymmetry, this is explained by the fact that one party has some information that the other one does not. Secondly, the uncertainty of the results, this means that all the participators are similar, and remain all responsible for the results' accomplishment. And finally, roles disparities, this means that each party possess their own responsibilities directed by the Principal through determined rules. Jensen and Meckling (1976) define an agency relationship as "a contract under which one or more persons (the principal(s)) engage another person (the agent) to perform some service on their behalf which involves delegating some decision-making authority to the agent".

From a transfer pricing strategy perspective, MNCs possess relevant information that tax administrations ignore, such as: the functional analysis results, the comparables sources, the intragroup transactions conditions and all the information in relation to the organisation's different activities. The tax administrations can also be provided different transfer pricing information by other tax authorities, in respect of the audited MNCs. Accordingly, the existence of the informational asymmetry results in creating a sort of complexity in the relationship between MNCs and tax administrations. The discrepancy in terms of both parties' objectives 10 result in creating conflicts between them. The conflicting objectives create undoubtedly opportunistic behaviors. The Agency theory is based on objectives' incongruence in respect of the principal and the agent. Consequently, the risks associated with achieving the objectives of the contract set between the two parties increase. It is evident that the dichotomous relationship, between tax administrations and MNCs operating in a complex environment and structuring their 
intragroup transactions prices, is to be placed and explained under the Agency Theory. However, when both tax administrations and MNCs collaborate together in setting regulated transfer pricing strategies, the Stewardship Theory can be used in order to explore this process. This theory may be considered as an alternative or a complementary theory to the Agency theory. The Agency theory focuses on the conflictual relations that exist between two parties, whereas, the Stewardship theory focuses on the cooperation and the collaboration between the two parties (Sundaramuthy and Lewis, 2003). In this respect, this theory aims to explain the existing relationship from a non-economic perspective. The Stewardship theory suggests that the two parties' objectives converge (Sundaramuthy and Lewis, 2003; Kluvers and Tippett, 2011). Therefore, the two participants (for instance the tax administration and the MNC) work together in order to meet the common objectives set. Accordingly, both parties operate in collaboration towards each other without adopting opportunistic behaviors and personal interests (Stout, 2003). This theorises the commitment to wellbeing, growth, and the completeness of others (Caldwell and Karri, 2005). Generally, the Stewardship theory highlights the perspective that individuals act continually under considerations of fairness, justice and concern for others' interests 11 (Buchanan, 1996). Similarly, to the Agency theory, the Stewardship theory emphasizes the need to align the objectives of the agent with those of the principal (Arthurs, 2003). However, the Stewardship theory assumes that the objectives of the two parties are automatically aligned (Pastoriza and Arinio, 2008). Ultimately, while the Agency theory postulates individualism, the Stewardship theory advocates collectivism.

In respect of transfer pricing strategies, MNCs may operate to satisfy tax authorities wellbeing and motivations. By avoiding abusive profit shifting and aggressive tax optimisation practices, a multinational enterprise set its transfer pricing policies in order to mainly assure tax compliance towards all the tax administrations. Thus, MNCs operate in accordance with the international taxation principles based on equity and integrity, to reduce the inequalities between jurisdictions, and help in the fair distribution of wealth. Accordingly, MNCs may align their transfer pricing strategies in correspondence with the international guidelines and regulations as set by the OECD and the UN for instance. Therefore, according to the Stewardship theory, MNCs avoid practices based on transfer pricing manipulation. They tend to agree with the tax administrations and initiate collaborative procedures such as agreements based on mutual engagement and trust. Both parties interact in perfect harmony in order to attain their inseparable goals.

Based on this two theories, our study suggests a theoretical framework (below), to analyse the connection between tax administrations and MNCs regarding transfer pricing strategies, assuming that each with their own motives, may interact with each other in order to find a fair consensus that should be based on trust and mutual engagement.

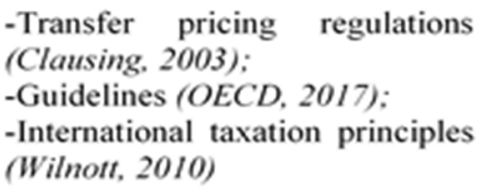

-Organisational objectives: costs cuts, resource allocation (Urquidi, 2008);

-Tax optimisation (Matsumura and al, 2012)

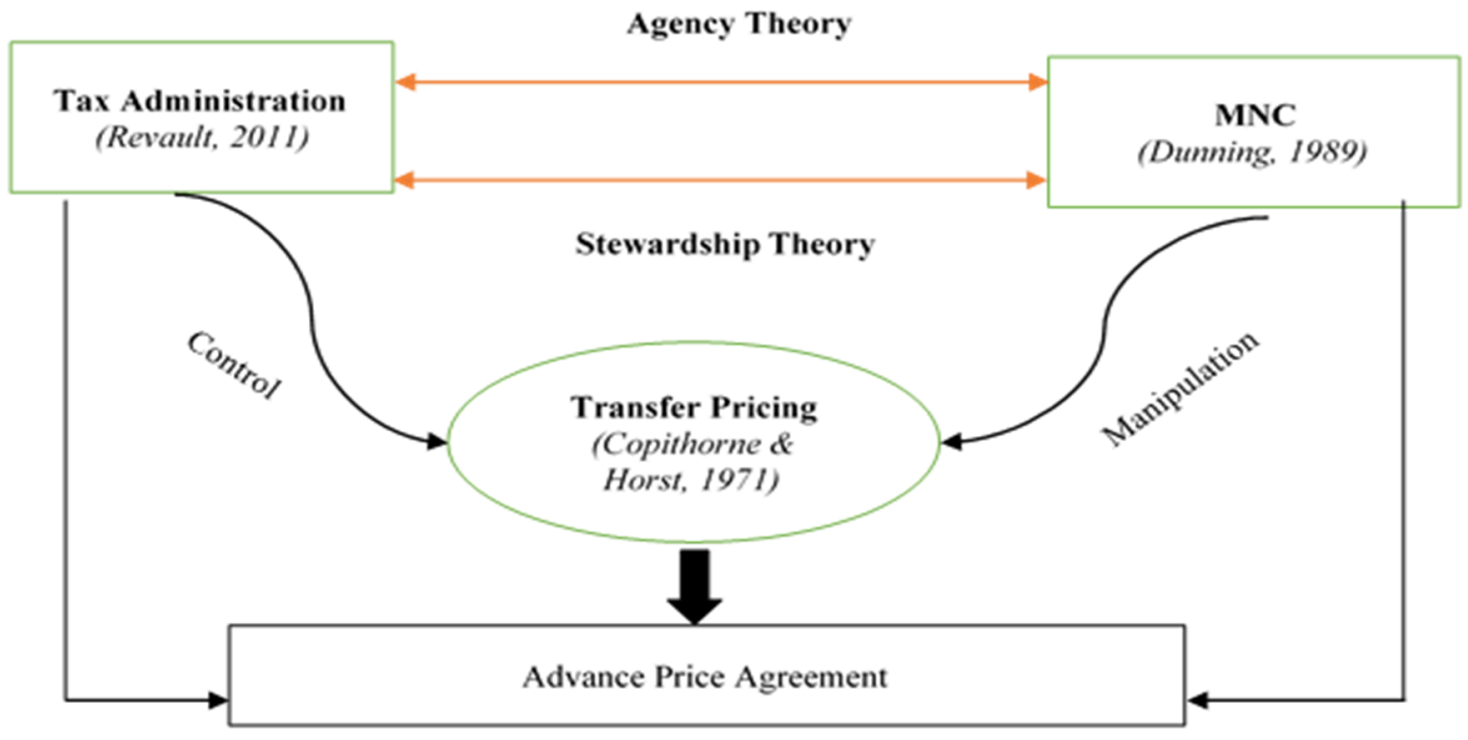

3. Research strategy and design

We adopted a qualitative exploratory study based on semi-structured interviews. The exploratory methods respond to "why" and "how" research questions. In management researches, empirical methods (different observation 
forms, interviews, investigations etc.) are often used in order to explore and establish new theoretical objects rather than testing them (Snow and Thomas, 1994). This study is conducted under exploratory research, it consists in going back and forth between our theoretical knowledge on one hand, and through interviews' findings on the other hand. The aim of the study is to explore whether the Advance Price Agreement can be considered as a solution to reduce conflicts between tax administrations and MNCs in terms of their transfer pricing policies. However, it is first convenient to examine the importance of transfer pricing for MNCs, and explore the impact of the tax administrations controls and audits on transfer pricing policies. The objective is to comprehend the conflicts that may rise between the both parties, and finally, see whether the APA may be a solution.

In order to complete the study, we have concluded 20 depth interviews, and analysed documents in relation to transfer pricing from both the tax administration's perspective and the MNC's perspective. The interviews were in form of open discussions, to encourage the interviewees to willingly talk about our subject, based on the experiences they had when working in transfer pricing. These selected interviewees have firstly been contacted via email, explaining the purpose of our study, and they were all immediately responsive. We have then fixed dates to schedule our meetings. The respondents' selection has been accomplished on the basis of their high implication about transfer pricing practices in different countries (both developed and emerging ones). In fact, we have contacted various multinationals' tax heads, transfer pricing specialists of big 4 firms, international transfer pricing advisors. They all have quite interesting profiles of an average of 20 years of experience in transfer pricing, practicing in different countries (USA, France, Canada, Morocco, Singapore, UAE, Italy, India, Nigeria, Austria, Ireland, England, Egypt, Norway, Luxembourg, Netherlands). They are responsible of implementing transfer pricing policies by accomplishing all types of analyses and selecting the transfer pricing method. They also deal with the tax administrations during transfer pricing audits. Moreover, they have all addressed APAs with the tax administration. In that respect, they have been part of the APA process, which provides them enough with the necessary knowledge about APAs' relevancy.

Based on our literature review and theoretical framework, we have established our interview guide containing open questions, in order to open our discussions regarding the importance of transfer pricing, transfer pricing motives for both MNCs and tax administrations, the tax administration's impact on transfer pricing strategies set by MNCs, the reasons of conflicts raised between both parties about transfer pricing, and finally the significance of the APA conclusion in reducing controversy between MNCS and tax administrations.

The interviews were performed in an average of one hour and thirty minutes. Accordingly, the interviewees are presented in the table below:

\begin{tabular}{|l|l|l|}
\hline Interviewee & Function & Duration \\
\hline I 1 & Head of Transfer Pricing in a multinational Law firm, Morocco & $2 \mathrm{~h}$ \\
\hline I 2 & Senior Tax Manager in a big 4 firm & $1 \mathrm{~h}$ \\
\hline I 3 & Transfer Pricing Partner in a big 4 firm & $1 \mathrm{~h} 30 \mathrm{mins}$ \\
\hline I 4 & Transfer pricing Head in a consultancy firm & $45 \mathrm{mins}$ \\
\hline I 5 & Transfer Pricing Head in a big 4 firm & $1 \mathrm{~h}$ \\
\hline I 6 & International Tax Advisor in a consultancy firm & $1 \mathrm{~h} 30$ \\
\hline I 7 & Transfer Pricing Head in a big 4 firm & $2 \mathrm{hours}$ \\
\hline I 8 & Transfer Pricing Lawyer in a big 4 firm & $1 \mathrm{~h} 30 \mathrm{mins}$ \\
\hline I 9 & Tax Head in a telecommunications multinational & $1 \mathrm{~h}$ \\
\hline I 10 & Tax Lawyer in a consultancy firm & $1 \mathrm{~h} 30 \mathrm{mins}$ \\
\hline I 11 & Group Head of Tax in a manufacturing and distribution Multinational & $1 \mathrm{~h} 30 \mathrm{mins}$ \\
\hline I 12 & Senior Tax Officer in a tax administration & $1 \mathrm{~h} 30 \mathrm{mins}$ \\
\hline I 13 & MNCs Control Head in a tax administration & $1 \mathrm{~h} 30 \mathrm{mins}$ \\
\hline I 14 & Regional Director in a tax administration & $1 \mathrm{~h} 45 \mathrm{mins}$ \\
\hline I 15 & Tax inspector in a tax administration & $1 \mathrm{~h}$ \\
\hline I 16 & Tax and Law expert and advisor & $1 \mathrm{~h} 30$ \\
\hline I 17 & Head of Transfer Pricing Strategy and Operations in a Pharmaceutical & $1 \mathrm{~h}$ \\
\hline I 18 & Multinational & \\
\hline I 19 & Transfer Pricing and International Taxation Attorney & $1 \mathrm{~h} 40$ \\
\hline I 20 & Transfer Pricing Group Head in a telecommunications and IT multinational & $1 \mathrm{~h} 20 \mathrm{mins}$ \\
\hline
\end{tabular}

\section{Research findings and discussions}

Our interviews addressed open questions, while focusing on four important aspects. First, the definition of transfer pricing importance nowadays. Then, the impact that may have the tax administration (via its audits and regulations) on MNCs' transfer pricing strategies. This control, leads sometimes to conflicts between both parties for reasons that may differ from one case to another, however, the interviewees provided us with answers through practical 
experiences with the tax administrations. Lastly, through the discussions, we assessed whether the APA can be considered as an efficient tool to reduce these oppositions between tax administrations and MNCs when dealing with transfer pricing issues.

\subsection{Transfer Pricing Importance}

The international business environment evolution has resulted in many changes in respect of the international tax environment. In fact, competition was born between the different countries, when these jurisdictions adopted different tax regimes and business environments. In this respect, companies are able to choose the country in which operating their activities would be the most beneficial. "These companies have noticed that there is a different tax system from one jurisdiction to another... so, this opens up to the possibility of tax optimisation. As long as there is competition between tax systems, we open the way to optimising an effective tax rate... by increasing revenues on one side and reducing expenses on the other" (I1). Therefore, because the tax environment largely impacts the MNCs functional strategies, these can use transfer pricing mainly for tax optimisation purposes, "Transfer pricing is clearly the main international taxation issue caused by multinational enterprises... they are considered as the big boom... because 2/3 of international trade is intragroup, this means that the trade that generates real value represents only 1/3, the remaining is intragroup" (I2). Even if there are many non-tax related transfer pricing motivations for MNCs (new markets access, competitiveness, production increase), the manipulation of these prices results in colossal damages. "The OXFAM valued the shortfall for tax administrations at 20 billion dollars annually due to transfer pricing manipulation... the work of the OECD and the G20 are performed in this respect... their main objective is to limit the international tax fraud, particularly in terms of transfer pricing policies" (II). However, transfer pricing policies are not always implemented strategically, "Some organisations treat their transfer pricing policies as a simple tax compliance practice... by setting up transfer pricing documentation and justifying the method adopted. Others treat it as a useful supply chain tool or treasury function tool. Naturally, there are also MNCs that use transfer pricing policies as a tool to manage effective tax rates" (I14).

It is, indeed, very crucial for MNCs to implement a well-structured transfer pricing strategy for different reasons, whether the goal is to remain compliant with the different tax regulations, or achieve financial objectives. Because transfer pricing combines different jurisdictions, the issue occurs when there is a dispute between the concerned countries. In this situation, "it's the MNC that gets scratched between the two tax authorities, and "often the MNC doesn't care that much about the price as long as the tax administrations agree that there is no economic double taxation...So avoiding any sorts of disputes with the tax authority regarding transfer pricing is a major driving force for multinationals to adopt transfer pricing strategy, you see that with the Advance Price Agreements procedures" (I6).

Transfer pricing exists because multinational enterprises exist, it is therefore a subject that cannot be underestimated or neglected. MNCs are aware more than ever of the importance of setting the right transfer pricing policy for their intercompany transactions. This would assist them in the correct profit allocation along the different jurisdictions. Transfer pricing can also be perceived as a performance risk management tool, depending on how an entity within the group is performing the business activity. Then, there are, obviously, the different tax implications that need to be considered, in order to comply with each country's internal transfer pricing regulations. Although, many countries try to adopt a unified approach in respect of transfer pricing, there are few countries, for instance Brazil, that hold specific transfer pricing rules. It is important to note that "the multinational looks at itself as a single organisation, not as hundred entities... that is just a legal fiction" (I19). This approach doesn't necessarily fall under the tax administrations scope, that can adopt many different interpretations.

\subsection{Tax Administration's impact on MNCs' transfer pricing strategies:}

"The tax administrations should not impact the transfer pricing strategies of the multinational" (I12). Transfer pricing should be looked at as a discipline, that tax administrations only regulate by enforcement and audit activities. Undoubtedly, there are diversions in the ultimate goals of the both parties, that would automatically create tensions, and therefore, oppositions. For this reason, MNCs must take into consideration the tax authorities of all parties that are engaged in a certain transaction from the moment where they are deciding the exact scope of work and the remuneration and pricing policy. This would, clearly, ease all their business operations in the different countries, and especially, make them aligned with the expectations of all tax authorities.

However, it is evident that business drives tax and not the opposite way. This being said, that companies adapt their business to the tax implications. "I think I have never seen any company change its strategy just because of the aggressive approach of the tax authorities...even if the tax administration here in India is very aggressive." (I7). In fact, the impact depends on the size of the country. "The tax authorities in the bigger countries such as the US, have bigger impact" (I17), a MNC would definitely consider the tax regulations in a big country (for instance, OECD countries) as these tend to have advanced transfer pricing regulations and audits. Countries where the transfer pricing legislation is not pushed to a high level (for instance, few African countries and Middle East countries) would not impact MNCs' transfer pricing policies. "Before designing our transfer pricing strategy, we 
first look at the country where it is better to operate, because of course tax authorities impact transfer pricing strategies because each country has its own regulatory.... for example, when we are dealing with China or Russia, they do not recognize year-end adjustments, this pushes us to implement a policy that we should be able to manage" (I9) In addition, "for example, in Brazil, there is the safe harbor rule, so in this case there isn't much to do except sticking to the safe harbor rule" (I16). These elements, evidently, influence the choice of the transfer pricing plan to implement.

Transfer pricing has gradually developed, there are new transfer pricing perspectives and new assessments regularly in order to frame transfer pricing practices. These developments and improvements are pretty much driven by the tax authorities. "It is some sort of cat-and-mouse game between the MNC and the tax authorities... these try to set new rules every time the MNC comes up with a new way to shift profits, and this goes on and on for many decades" (I10). These new rules come together with assessments and adjustments, this is something that makes MNCs respect the rules. They know that there are important financial and reputational risks, if they don't follow the transfer pricing guidelines.

Therefore, tax authorities play an important role in the definition of transfer pricing policies by MNCs. These need to make sure that their transfer pricing strategies are compliant with the transfer pricing rules of each country. "The most important tax issue for all jurisdictions is undeniably transfer pricing, because that is where the jurisdictions have most of gains" (I8). Some tax administrations are considered aggressive, others not so much. "Unfortunately, now with the COVID-19 crisis, tax authorities will become more aggressive, because they need to increase their tax revenues due to the financial crisis." (I19). This means that there will be more transfer pricing audits, and therefore more assessments and tax adjustments. "The administrative factor is very important in this situation" (I18).

\subsection{Conflicts reasons between tax administrations and MNCs}

All the respondents argued that there is a real conflict between MNCs and the tax administration in terms of transfer pricing policies, "they have different objectives, tax authorities want to maximise their own tax base, sometimes at the cost of MNCs...sometimes at the cost of other countries." (I5). From this perspective, several international organisations (such as the OECD and the UN) have introduced a number of measures and have recommended to many countries to incorporate these procedures into their internal regulations, in order to soften the oppositions between both parties. Therefore, align all the countries in one unified approach. Yet, countries may differ on the approach used in their internal transfer pricing rules, "in case of developing economies, tax authorities can get very aggressive, and that is the practical reason of conflicts" (I11). The real consensus begins with adopting a structured and fair legislation first, then argue about the transfer pricing method selected during the audits, "the conflict is about the different interpretation of the facts... sometimes they agree on the facts but differ on the rules, but usually it's about the facts." (I13). One important source of the confrontation is the miscommunication, "the best way to reduce conflicts is to have an open relationship with the tax authorities based on mutual trust, respect and willingness to be pragmatic... well, this is the ideal and may not be possible in every jurisdiction" (I18). Documentation, functional analysis, used data are all components that need to be communicated between the two parties in order to determine and agree on the right transfer pricing method. "The tax administration abuse of its power, sometimes they would reject the transfer pricing method, without even requesting the documentation... This leads the MNC to loose trust when dealing with the tax administration" (I2).

"Transfer pricing is a full of interpretation, it is not a black on white procedure" (I15), this leads to adopting different point of views on what is the correct approach to use. Conflicts may concern different aspects: the functional analysis, the economic analysis, the comparables' selection etc. "In my opinion, the main reason of conflict is the selection of the wrong comparables...it can also be the use of the wrong transfer pricing methodology" (I20) In fact, there are countless reasons of conflict, but what really accentuates this opposition is mainly the miscommunication between both parties, "no matter how well we do, we are always afraid of the bad intentions of the tax administration" (I17). "it is very hard for us (tax administration) to obtain the right information about transfer pricing during our audits, the reason is that the transfer pricing documentation is still not required...this pushes us to question every single transaction... in the other hand, the MNC does not accept the fact that we reject a price for example for management fees. We also try to not make them angry, as they are doing so much for our economy" (I14). It is clear that conflicts' nature differs from one jurisdiction to another, it mainly depends on how structured and advanced the transfer pricing legislation is. "The tax administration is so aggressive, they reject transfer pricing methods all the time" (I7).

Another reason may be the lack of transfer pricing experts in the tax administration, this is particularly concerns the emerging countries, where transfer pricing rules have just been set up recently. "It is very hard for us to discuss advanced transfer pricing matters with inspectors who don't really have a technical background to understand our approach, this happens a lot in few African and Asian countries, where transfer pricing legislation is not sophisticated" (I8). This can considerably impact the MNC choice of implementing its operation in this kind of countries, "we should think a lot before choosing a country.... The attitude of the tax administration towards 
transfer pricing audits is very important, as it would have significant impacts on our operations in that country" (I19).

The conflict between the tax administrations and MNCs exist, however, many solutions to reduce these divergences may be adopted. The OECD has introduced the Advance Price Agreement as one of the tools to reduce the divergence that may occur between both parties. In fact, the MNC has the possibility to request to conclude an APA, in order to secure the transfer pricing method.

4.4. APA's accuracy in reducing controversy

MNCs seek after all, the risk avoidance. By concluding an Advance Price Agreement, they limit tax and financial risks. They make sure the transfer pricing method used for a certain type of intercompany transaction is being accepted by all the tax administrations involved. Therefore, it is clear that Advance Price Agreement are introduced in order to reduce conflicts between the tax administration and the MNCs. "The absolute purpose of the APAs is definitely to reduce conflicts between these conflicts, however the changes in circumstances should be kept in track" (I5). "In fact, APA scheme has been very successful in India, it is much better than the regular course of tax audits. APAs as a dispute mechanism has been really good in India in terms of resolving tax disputes" (I7). "I am delighted to see that Morocco has introduced the APA option, because it's time for us to adopt a similar approach as the developed countries, if we want to encourage foreign investment... and maintain MNCs activities here" (I2). "The APA is a very useful tool to reduce controversy with the tax administration, or the ICAP concept, which is a program where multiple countries agree to start a cooperative compliance with certain multinationals around the world, and in this program MNCs are able to secure the transfer pricing policy... have access to sign an APA with all the tax authorities of the countries that are participating to the ICAP this means that you will be able to have all the tax authorities of the countries participating in the ICAP sitting in the same table and agreeing on the risk assessment based in the transfer pricing policy and risk profile" (I9). "If a particular company for any reason is highly likely to be audited then it seems to me to make a lot of sense for them to have an APA and try to get an agreement in advance with the tax administrations, because ultimately neither the government nor the multinational can afford for every case to go to court" (I15). Many countries have introduced the option to conclude APAs in their internal transfer pricing legislations, as encouraged by the OECD. APAs present, in fact, many advantages for MNCs. However, they can be very costly in terms of resources and time. Tax administrations need to have dedicated transfer pricing specialists, to be able to properly examine the transfer pricing method selected by the MNC.

Many interviewees confirmed that they don't recommend their clients (MNCs) to use the APA approach, as it is sometimes tricky to convince a tax administration that the method used is the correct one, and that the functional analysis completed is accurate. It has been noted that it actually depends on the country the MNC is dealing with. "I concluded an APA with the tax authority in the Netherlands a few years ago, it was pretty much straightforward because the tax administration there is very sophisticated and has a lot of experience in transfer pricing. They encourage business, so we came to an agreement very quickly. Being a group tax head in Dubai, I wouldn't take this option with the tax authority here... unless we really have a risky business and the margins are low. However, if I was in India, I would prioritise the APA option as their tax administration is very aggressive. So for me, it really depends on the country" (I11).

"it depends on the risks and the country, it depends on the amount of money involved. If I have a very important intercompany transaction between two big markets of course I would like to get an approval of the transaction by the tax authorities. So there I try to make risk adjustments, try to differentiate between countries where the issues are complex, and of course the attitude of countries, if the tax authority is known for being very aggressive in audits, I will have a different approach in that country but if it is a country where the tax authority has no interest in transfer pricing, you don't pay too much attention" (I17). "I had at some point concluded an APA with UK, Belgium, Spain and Italy and I would show those off to other countries to explain that the model and the margins have been vetted by OECD tax authorities - that would usually work fine..." (I19).

Sometimes, MNCs are afraid to approach the tax administration with an APA request, because this can cause a wild exposure, and therefore, a critical tax risk. This would therefore, increase controversy between both parties. "Worthy to mention is that applying for an APA is not always an assurance that the case will get approved and be a successful case so MNCs have to be prepared. The risk for applying for an APA that will not get accepted is that we raise a flag for the tax authority on the potential problems and loopholes in the transactions and the policies applied" (I3). "Theoretically this is the best solution, but in practice it is a tool that does not work very well, because it takes a long time and the administration lacks the resources to handle all the files. On the other hand, it grants security, this is the key in all groups" (I18).

APAs can certainly reduce controversy, but can also be the reason of conflicts. The jurisdictions need to first create a climate of trust, and establish mutual honest understanding relationships between tax administrations and MNCs. This is the only way to make these agreements work and therefore cut the oppositions. "I don't think that there is a company that has made a prior agreement with the tax administration of a country in the Middle East. 
The approach is very difficult. The simple reason is that we do not know the outcome of the discussions with the tax administration. We cannot approach them without having a feeling of comfort that things will be positive" (I11). "I think controversy wouldn't exist between MNCs and tax authorities if there is a feeling of safety, which is mainly generated by the mutual trust. Unfortunately, most of the times, the tax administration comes with the idea that the company's main goal is the profit shifting and the transfer pricing manipulation..." (I4). "In order to maintain a harmonious business climate for MNCs, everybody should take a step in being transparent... when requesting an APA, the MNCs need to be sure that the tax administration is in an open discussion approach" (I6). The Advance Price Agreement can be considered as an option to reduce controversy, however, it needs to be set in a transparent environment, where all the parties are willing to engage in order to find the right consensus about transfer pricing divergence. Emerging economies, in particular, need to implement structured legal and administrative reforms to their internal transfer pricing policy first. Whereas, developed countries have to reinforce their transfer pricing guidelines, for them to be adapted with all the new business models.

Hence, the empirical findings have completed the theoretical framework and can therefore be summarised below:

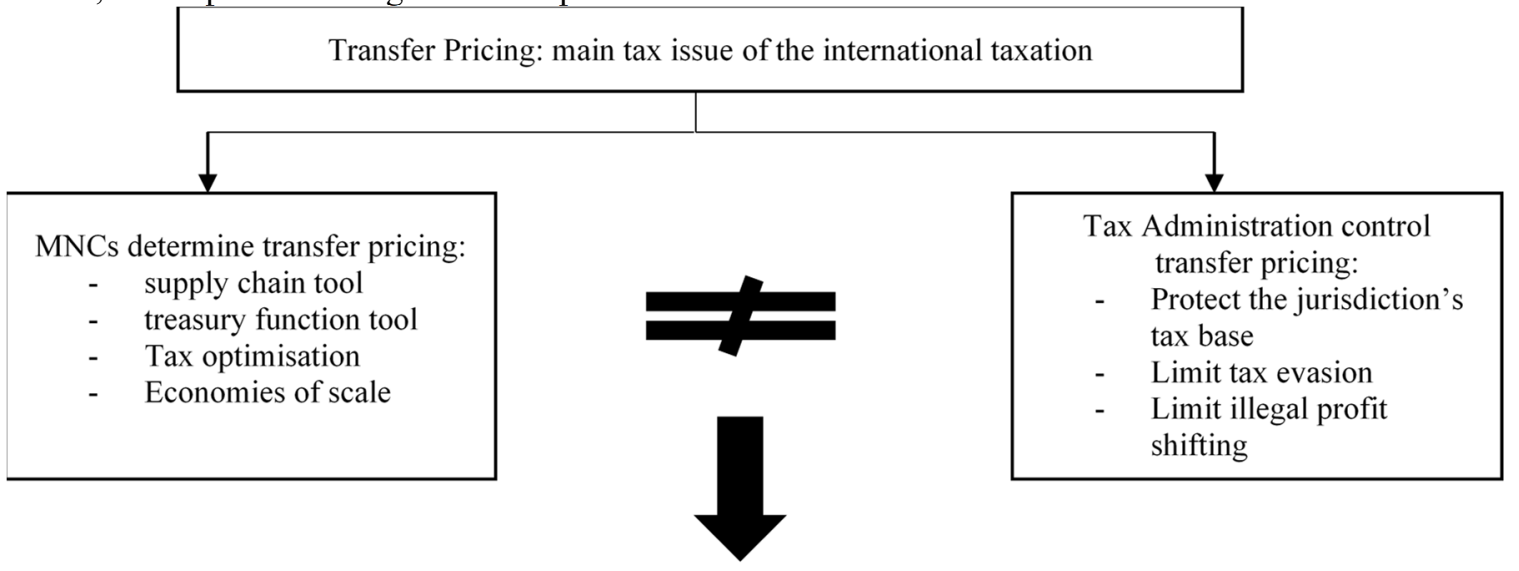

Advance Price Agreement is an option to reduce controversy between MNCs and Tax Administrations if:

- A climate of mutual trust is set between parties;

- The tax administrations are sophisticated in terms of transfer pricing;

- The tax administrations adopt less aggressive approaches during transfer pricing audits;

- $\mathrm{MNC}$ is willing to provide all the necessary information to the tax administration

- Both parties are transparent with each other when discussing APA conditions;

\section{Conclusion}

Because they defend different objectives, tax administrations and MNCs may be in different conflictual situations in respect of transfer pricing problematics. The OECD is working towards finding solutions for both parties, and to clarify what would be the best approach. The UN is also encouraging both developing countries and developed economies, to adopt the international transfer pricing guidelines. The aim is to implement a unified approach in the different jurisdictions. However, there are still many disparities between the countries, this is explained by the fact that the advanced countries have been dealing with transfer pricing and MNCs for many decades (for instance the US). Many African countries have just seen MNCs establishing their subsidiaries in their jurisdictions, this makes transfer pricing quiet a new subject for their tax authorities.

Nevertheless, many countries are adopting the OECD guidelines in their internal respective policies. The APA has largely been adopted in many jurisdictions, it is very successful in many countries, where MNCs prefer to secure their transactions' prices. However, it is still criticized in other economies, for different reasons such as the incompetence and the aggressiveness of the tax authority. From this perspective, to make APAs work and therefore, avoid controversy, both the MNC and the tax authority have to set collaborative approaches based on partnerships. This will lead to the protection of the jurisdiction's tax base, and secure compliant tax optimisations for the MNC. Both parties need to adopt open discussions for information exchange, they need to remain objective when discussing transfer pricing issues. In this respect, APAs would be encouraged and used widely. Concluding APAs would, indeed, help both parties in making sure to expect the most efficient outcome from a transfer pricing strategy.

Actually, the challenge for the tax authorities is to adapt their legislations to the new business models related, for instance, to technology companies. These cannot be treated the same way as the other types of companies, 
because the value within the value chain is created differently. These new business models have heightened conflicts with the tax authorities, due to their specific functioning. Consequently, the OECD is currently working on new transfer pricing rules adapted to these companies.

\section{References}

Adams, c., and coombes, r.. (2003). Global transfer pricing: principles and practice, london: lexisnexis tolley.

Aranoff, g. (2000). Transfer pricing with technology choice and demand fluctuations in a simple manufacturing model, quarterly journal of business and economics, 39(2) : 2-5.

Argyris, c. (1957). Personality and organization; the conflict between system and the individual. Oxford, england: harpers.

Arthurs, j. (2003). The boundaries and limitations of agency theory and stewardship theory in the venture

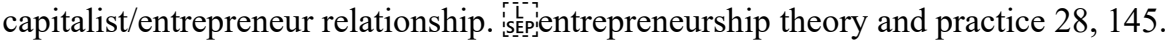

Baker., rw. (2005). Capitalism's achilles heel. New jersey: john wiley

Basu, a., lai, r., srinivasan, v., \& staelin, r. (1985). Sales- force compensation plans: an agency theoretic perspective. Marketing science. $4: 267-291$

Becker., b, davies., r, jakobs, g. (2017). The economics of advance pricing agreements. Journal of economic behavior and organization 134 (2017): 255-268

Borkowski, s. (2008). The history of pata and its effect on advance pricing arrangements and mutual agreement procedures. Journal of international accounting, auditing and taxation. 17 (1) : $31-50$.

Brem, m. (2005). Globalization, multinationals and tax base allocation : advance pricing agreements as shifts in international tax policies?. Iima working paper, no. 2005-12-01.

Buchanan, a. (1996). Towards a theory of the ethics of bureaucratic organizations. is ispusiness ethics quarterly 6 (419).

Caldwell, c. And karri, r. (2005). Organizational governance and ethical systems : a covenantal approach to building trust. Journal of business ethics 58 (249)

Cazal d. (2006). La rse et ses parties prenantes : enjeux sociopolitiques et contrats, document de travail du lemcnrs n ${ }^{\circ} 2006-06$

Cecchini m., leitch r., stobel. C. (2013). Multinational transfer pricing : a transaction cost and resource based view. Journal of accounting literature 31(2013) : 31-48

Chang, s., witteloostuijn, a. And eden, 1. (2010). From the editors: common method variance in international business research, journal of international business studies. 41( 2) :178 - 184 .

Choe, c., and hyde, c. (2004). Multinational transfer pricing, tax arbitrage and the arm's length principle. Discussion paper.

Clausing., ka. (2003). Tax-motivated transfer pricing and us intrafirm trade prices. Journal of public economics. 87(9/10):2207-23.

Copithorne, 1. (1976). La theorie des prix des transfert internes des grandes societes. L'actualite economique 52 (3) : 324-352

Cotter, j., tuna, a. I., wysocki, p. D. (2006). Expectations management and beatable targets: how do analysts react to explicit earnings guidance? Contemporary accounting research 23 (3): 593-624.

Cravens, k. (1997). Examining the role of transfer pricing as a strategy for multinational firms. International business review. $6(2): 127-145$.

Davidmann, m. (1996). Community economics, multinational operations: transfer pricing. Vergi uygulamalari açisindan transfer fiyatlari, vergi dünyasi (19) : 66-73

Dean, j. (1955). Decentralization and intra-company pricing. Harvard business review. 33 (4) : 65 - 74.

Delalande, n. (2011). Les batailles de l'impot. Consentement et resistances de 1789 a nos jours. The english historical review 27 (529) : 1607-1609.

Demski, j. And g. Feltham. (1976). Cost determination: a conceptual approach. Ames, iowa: iowa state university.

Doyle, p. (1994). Il n'y a de saine performance que dans l'equilibre. L'expansion management review (74) : 38 47

Dunning, j. (1979). Explaining changing patterns of international productions: in defence of the eclectic theory. Oxford bulletin of economics and statistics 41 (2) : $269-295$.

Dunning, j. (1980). Towards an eclectic theory of international production: some empirical tests. Journal of international business studies, $11(1): 9-31$.

Dunning, j. (2000). The eclectic paradigm as an envelope for economic and business theories of mne activity. International business review. 9 (1) : $163-190$.

Eccles, robert g. \& white, harrison c. (1988). Price and authority in inter-profit transactions. American journal of sociology. 94. Pp. S17-s51.

Eisenhardt, k. (1989). Agency theory : an assessment and review. Academy management review 14(1) : 57-74

Emmanuel, c. And mehafdi, m. (1994). Transfer pricing, london: the chartered institute of management 
accountants and academic press.

Ernst \& young. (2005/2006). Global transfer pricing survey, september, bahamas: eycg limited.

Ernst \& young. (2007/2008). Global transfer pricing survey: global transfer pricing trends, practices, and analyses,

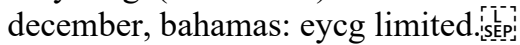

Fama, e. (1980). Agency problems and the theory of the firm. Journal of political economy. (88) :288-307.

Gao, 1., zhao, x. (2015). Determining intra-company transfer pricing for multinational corporations. International journal of production economics 168 (2015) : 340-350

Gramlich jd, wheeler je. (2013). How chevron, texaco and indonesian government structured transactions to avoid billions in us income tax. Accounting horizons.17(3):107-22.

Harden, j. And biggart, t. (2004). Advance pricing agreement: a chance for certainty in the midst of chaos. Strategic finance. $86(4): 11-12$.

Heflebower, r.b. (1960). Observation on decentralization in large enterprises j. Ind. Econ, 1960 (9) : 7-22

Hernandez, m. (2012). Toward an understanding of the psychology of stewardship. Academy of management review. 37 (172).

Hirshleifer, j. (1956). On the economics of transfer pricing. The journal of business 29(3) : 172-184.

Horst, t. (1971). The theory of the multinational firm: optimal behaviour under different tariff and tax rates. Journal of political economy 79 (1) : 10-59.

Jensen, m.c. and meckling, w.h. (1976). Theory of the firm: managerial behavior, agency costs and ownership structure. Journal of financial economics, (3) : 305-360

Kachelmeier, s. J. And k. Towry. (2002). Negotiated transfer pricing: is fairness easier said than done?. The accounting review $77(3): 571-593$.

Kimberly a. Clausing. (1998). The impact of transfer pricing on intra firm trade. Nber working paper 6688. National bureau of economic research,

Kluvers, r. And tippett, j. (2011). An exploration of stewardship theory in a not-for- profit organisation. Accounting forum 35,275

Kosnik, r. (1987). Greenmail; a study in board performance in corporate governance. Adminisfrative science ouarterly. (32) :163-185.

Kroppen, h., r. Dawid, schmidtke r. (2012). Profit split, the future of transfer pricing? Arm's length principle and formulary apportionment revisited from a theoretical and a practical perspective. W. Sch on, k. A. Konrad, eds., fundamentals of international transfer pricing in law and economics. Springer.

Leitch, r. And barrett, k. (1992). Multinational transfer pricing: objectives and constraints. Journal of accounting literature. $11(1): 47-92$.

Leroy, m. (2009). La sociologie fiscale. Socio- logos, (4) :1-30

Liu, li. (2017). Where does multinational investment go with territorial taxation? Evidence from the uk, oxford university centre for business taxation. Working paper 1705

Luft, j. And r. Libby. (1997). Profit comparisons, market prices and managers : judgments about negotiated transfer prices. The account-ing review $72(2): 217-229$.

Markham, m. (2012). Advance pricing agreements: past, present and future. The netherlands: kluwer law international.

Matsumura, t., \& matsushima, n. (2009). Cost differentials and mixed strategy equilibria in a hotelling model. Annuals of regional science, (43). 215-234.

Mitnick, b. (1966). The theory of agency and organizational analysis. Unpublished working paper. University of pitt burgh.

Mulyani, y. (2010). Factors influencing transfer pricing compliance : an indonisian perspective, phd in management sciences, sydney : univesrity of new south wales.

Nielsen, s. B, schjelderup, g. (2001). Formula apportionment and transfer pricing under oligopolistic competition. Epru

Oecd. (2011). Multi-country analysis of existing transfer pricing simplification measures, centre for tax and policy development, paris: oecd.

Oecd. (2017). Oecdtransfer pricing guidelines for multinational enterprises and tax administrations 2017, oecd publishing, paris.

Otley, d. (1980). The contingency theory of management accounting achievement and prognosis. Accounting, organizations and society. 5(4) : 413-428.

Oyelere, p. And emmanuel, e. (1998). International transfer pricing and income shifting: evidence from the uk. The european accounting review.7(4) : $623-635$.

Pastoriza, d. And arinio, m. (2008). When agents become stewards : introducing learning in the stewardship theory

Rawls j. (1988). La theorie de la justice comme equite $»$, in individu et justice sociale autour de john rawls, editions du seuil, paris. 279-317.

Revault p. (2011). La connexion comptabilite/fiscalite, a la fois simple et complexe, est-elle perenne?,cahier de 
recherche du creg, paris, fevrier.

Rossing, c., cools, m., rohde, c. (2017). International transfer pricing in multinational enterprises. Journal of accounting education 39 (2017) : 55-67

Sava, v., \& tureatcă, m. V. (2017). Transfer pricing - between optimization and international tax evasion. In s. Hugues, \& n. Cristache (eds.), risk in contemporary economy : 605-617.

Schillemans, t. And basuioc, m. (2015). Predicting public sector accountability : is isepififrom agency drift to forum drift. Journal of public administration research and

Sikka., p, willmott, h., (2010). The dark side of transfer pricing : its role in tax avoidance and wealth retentiveness. Critical perspective on accounting. 21 (2010):342-356

Snow c.c. et thomas j.b. (1994). Field research methods in strategie management : contributions to theory building and theory tes- ting, journal of management studies, 31,4, 1994.

Solomons, d. (1965). Divisional performance measurement and control, homewood, il.: r. D. Irwin.

Spence, a. M., 8 t zeckhauser, r. (1971). Insurance, information, and individual action. American economic fleview, (61) :380-387.

Stout, 1. (2013). On the rise of shareholder primacy, signs of its fall, and the return of managerialism (in the closet). Seattle university law review 36, 1169

Sundaramuthy, c. And lewis, m. (2003). Control and collaboration : paradoxes of governance. Academy of management review. 28, 397.

Urquidi, a. (2008). An introduction to transfer pricing. New school economic review 3 (1) $27-45$.

Urquidi, a. J., \& thompson, j. (2010). The challenge of transfer pricing in the asia pacific region. Asian journal of public affairs $3(1), 60-75$

Vanessa houlder. (2010). Tax haven drive will mean greater scrutiny, financial times newspaper march 20, london: the financial times limited.

Watson, d. And baumler, j. (1975). Transfer pricing: a behavioral context. The accounting review 50 (7) : $466-$ 474.

Wong, h., nassiripour, s., mir, r. \& healy, w. (2011). Transfer price setting in multinational corporations, international journal of business and social science, 2(9), 10-14.

\section{Notes:}

1 According to Emmanual and Mehafdi (1994), the theoretical organisational framework of transfer pricing includes aspects such as the understanding of the internal trade and the diversity of objectives that a transfer pricing system should achieve.

${ }^{2}$ The Contingency theory assumes that the organisation's structure is a form or "response" to an internal and external environment. Otley (1980) has shown that "contradictory results which cannot be solved in a universal framework, have been a source of simulation for development of contingency formulations". As a result, many researchers have used this theory to identify important contingent variables for transfer pricing.

${ }^{3}$ Preliminary transfer pricing studies and publications were developed in the 1950s and 1960s.

${ }^{4}$ For instance, Dean (1955), Hirshleifer (1956), Argyris (1957) and Heflebower (1960) studied the subject from the management perspective.

${ }^{5}$ Wong Nassiripour, Mir and Healy (2011) argue that in order to protect their tax bases, the governments of different countries, allow other countries' tax administrations to control and audit all intragroup transactions, and also penalise the company in case transfer prices are manipulated. The aim is to protect the national interest of each jurisdiction without prejudice to free competition (Sava and Tureatcā, 2017).

${ }^{6}$ In a multinational environment, the transfer pricing policy contributes to a large variety of goals, including profit maximisation, cash flow, sales and marketing goals, minimising taxes, duties and tariffs, and achieving sociopolitical goals related to financial restrictions, currency fluctuations and host country relations (Dunning, 1980; Leitch and Barrett, 1992).

7 The Advance Price Agreement (APA) has been introduced in the first time in 1985, when the national Japanese Agency has negotiated its first agreement. The American tax administration has then opened the door to agreements by implementing an APA program in 1991. Subsequently, the OECD has introduced its guidelines regarding APAs in 1995, by developing two elements. The first one, concerns the administrative approaches, and the second covers the APAs under the OECD mutual agreement procedure model (explaining the procedure by which tax authorities can resolve double taxation disputes).

${ }^{8}$ Some countries don't accept bilateral and multilateral APAs, unless there is a double tax treaty convention between them and the concerned countries.

${ }^{9}$ A contract can be defined as a series of clauses linking a combination of different possible primary elements to behavioral requirements (Schwartz, 2004). 
${ }^{10}$ For MNCs, the purpose of setting transfer pricing strategies can essentially be tax optimisation, costs cut, competitive production, global profit maximisation etc. Whereas, for tax administrations, the main objectives towards MNCs' transfer pricing policies, are essentially the maximisation of the tax revenues shared between the different concerned tax authorities. Another main goal is to reduce profit shifting practices and aggressive tax optimisations leading to tax evasion.

${ }^{11}$ According to the Stewardship theory, organisations' managers do not dissociate their interests from the interests of the firms. They operate under trust, and consider the company's objectives as their own personal goals (Hernandez, 2012; Schillemans and Basuioc, 2015). 